\title{
Virtual Tutor as an Assistant Technology Tool in Learning English in a School
}

\author{
Marcos Vinícius de Souza Toledo, Karina Dutra de Carvalho Lemos, Bruno de Souza \\ Toledo, Luiz Cláudio Gomes Maia \\ FUMEC University \\ Brazil
}

\begin{abstract}
With the advent of communication applications, information sharing has become faster and easier for people to exchange. This evolution of these applications allowed the majority of the population to have access to information, which brought significant changes in various areas of knowledge, especially in the academic field, where knowledge is discussed and constructed. The research problem was: What is the contribution of using virtual tutors in the learning process of students of integrated technical education? The aim of this paper was to analyze the use of virtual tutors by technical students of the Federal Institute of Minas Gerais in support of the content taught in the English Language course. This is a case study with qualitative characteristics. Data collection was carried out in a structured manner with students of Computer Technician courses. As a result, and solution of the research, it was found that students accepted the use of virtual tutors as pedagogical support in the contents taught and the activities proposed in the classroom in the analyzes performed by the answers to the questionnaires. As a contribution of this study it was found that: the use of technologies in education enabled a contextualized teaching, which valued the use of tutors as an aid in student learning.
\end{abstract}

\section{Introduction}

A current trend of self-regulated learning is that it occurs with the mixture of formal and informal forms of education, characterizing a possible change in the learning of new generations. Students from various institutions and countries constantly collaborate, share their knowledge, and seek information to solve or explain a problem at work, at school, or just to satisfy a curiosity. In addition, learning in the context of messaging platforms and social networks has become autonomous, self-motivated and informal, as well as an integral part of the experience of educational institutions [1].
However, most high school educational institutions in Brazil are stuck in traditional platforms such as assessment/learning systems and online course platforms that do not utilize the collectivity, autonomy and informality of social networks as pedagogical advantages in teaching, thus not allowing students to manage and maintain a learning space that facilitates their own activities, where they can practice and learn anytime and anywhere [2].

Another major challenge that Brazilian educational institutions currently face is foreign language teaching, as most students have difficulty learning a language.

A recent study by [3] demonstrated that "through a quantitative and qualitative, that the process of learning the English language is a complex system and that requires teachers and students to work together" in search of methodologies of individual and group learning for a good result in the study of that language.

In this respect, English learning technologies can go beyond traditional methods and provide students with a communication channel where they can practice writing, reading, comprehension and speaking. Allowing students not to be intimidated by their peers when learning any language.

The question that guided this research was: What is the contribution of the use of virtual tutors in the learning process of the students of the integrated technical education at the Federal Institute of Minas Gerais?

The article aimed to analyze the use of virtual tutors by technical students of a federal public education institution.

In this context, this study was justified by the advances in the teaching-learning process at school with the use of technological tools and how they help the students to search for new knowledge. The teacher in this technological scenario ceases to be the content transmitter and becomes the mediator in the process of research and construction of new knowledge 
through new computerized tools in the educational environment.

This paper is organized into seven sections. The first section presented the introduction, contextualizing the theme, the research problem, the objective and the justification of the study. The second, third, fourth, fifth and sixth sections contemplate the theoretical foundation, with points of view of several authors researched, for the theoretical basis of this study. The seventh section describes the methodological procedures of the article. The eighth section deals with data analysis and discussion of the results of this work. The ninth section describes the final considerations, what were the conclusions, the limitation and the suggestion of future research work.

\section{The Use of Artificial Intelligence in The Teaching And Learning Process}

Artificial Intelligence (AI) is a branch of computer science that proposes in the elaboration of devices that simulate the human capacity to reason, perceive, make decisions and solve problems, in short, the ability of a machine to be intelligent.

Artificial Intelligence is, on the one hand, a science, which seeks to study and understand the phenomenon of intelligence, and, on the other, an area of engineering, as it seeks to build instruments to support human intelligence [4].

With the emergence of the first computers there was a proposal of its use as a learning tool that were called Computer Assisted Instruction Systems (SIAC). These systems had some problems that were identified, such as: pedagogical rigidity, lack of adaptability to the characteristics of each student and the poor didactic potential development of these tools.

In order to remedy these shortcomings, new Artificial Intelligence techniques emerged that gave rise to Intelligent Tutors. These tutors allow for flexible system behavior and support for learning activities.

The intelligent tutors are computer programs for educational purposes that incorporate Artificial Intelligence techniques. They offer advantages over Computer Assisted Instructions because they can simulate the human thinking process to assist in problem solving or decision making.

According to Urretavizcaya [5], the most important characteristics of an intelligent tutor system in the teaching-learning process are: knowledge must be clearly articulated with the system, have student knowledge that allows it to direct and adapt to teaching, perform more tailored and detailed diagnostic processes and tutor-student communication improves, allowing the learner to ask questions to the tutor.

One type of intelligent tutor system used in education is virtual tutors, which will be described in the next section.

\section{Virtual Tutors in Education}

Virtual tutors are software that simulates human speech and are able to chat with users on Facebook and Telegram, for example. These tools use artificial intelligence. Virtual tutors can be of great help as educational assistants in the context where complex and practical questions need to be answered. In the most basic cases, one can recognize keywords to find in the database, more sophisticated operations that can be associated with natural language.

The interaction between humans and computer systems is shifting to natural language-based interfaces. Because artificial intelligence is based on the creation of machines capable of communicating with humans [6] and the fact that users prefer to use systems in natural language, there is the popularization of virtual tutors [7].

A good example in this context is the virtual tutor CHARLIE, this technology tool can send the material of a subject to the student, and then prepare questions associated with the material sent so that the acquired knowledge can be practiced.

The use of virtual tutors in specific teaching areas, especially in foreign languages can stimulate and encourage collaborative learning [8]. This can be an educational advantage, allowing the same technological tool to benefit other subjects in a school setting.

In the case of this research, the platform used by students in the English language subject is illustrated below in Fig. 1.

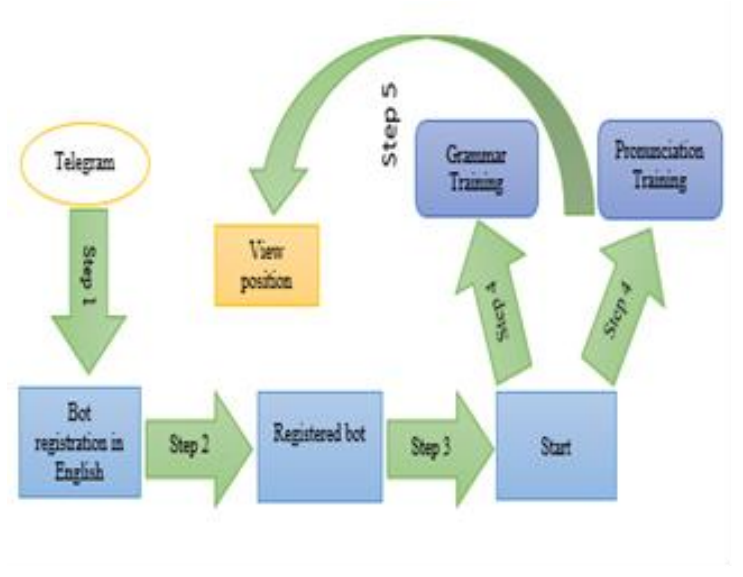

Figure 1. Five steps for using the virtual tutor bot

To use the virtual tutor, you must follow the five steps shown in the previous figure. To start the process of interaction with the virtual tutor, the user must have registered in the telegram messaging platform Step 1, this platform provides an interface for its users in mobile, web and desktop versions.

After registering on the platform, the user must enter the name of the virtual tutor in the contact search bar. To meet the requirements specified by the 
telegram platform, the name of the virtual tutor in question was defined as the bot's English Register. By filling in the search field with the name of the virtual tutor, steps 3 and 4 begin.

Clicking on the contact of the virtual tutor, presented in the search result, has the option Home. By performing step 4, user registration is automatically done on the server hosting the virtual tutor. Step 5 refers to user interaction with the training options offered. In this version of the virtual tutor, you are offered two training options:

- Grammar Training: This option allows the user to request a new grammar question in the Language English so that he can test his knowledge. In this option, when the user misses or hits, he/she receives feedback from your answer with tips on the question sent to him.

- Pronunciation Training: This option allows the user to request a new question so that he can train his pronunciation. In this option, the user responds by recording an audio and receives an answer about his pronunciation and also, if he answered the question sent to him.

With this the student's learning becomes more meaningful and comes closer to the knowledge acquired in his daily life. In the following section meaningful learning is described in the school context.

\section{Significant Learning in School Institution}

The computational resources used as pedagogical tools can help in the learning process, in which the student builds his knowledge through the articulation of ideas, producing explanations, understanding and meaning to solve the problems proposed in the classroom.

For Perrenoud [9] reports that, to be meaningful, knowledge implies the appropriation of what is abstract, that is, understanding, applying and transforming information, concepts, processes, facts, phenomena in order to contextualize them. For Jonassen [10] complements this idea by stating that the teaching-learning process should stimulate knowledge from the constructivist perspective, using dialogues and provoking interactions with oneself and with one another.

In constructivist theory, learning occurs in conjunction with experience gained in a school setting. "Knowledge is stimulated by the desire to understand phenomena and results from our understanding of our interactions with the environment" [10].
In this sense, students use technological tools in their learning process in order to assimilate and test the contents that are taught by the teacher in the classroom. With the use of these technologies, classes become more enjoyable, the learning process is more dynamic and arouses students' interest in the content taught. This idea is corroborated by Graells [11], stating that:

\begin{abstract}
Meaningful learning occurs when an open student dialogue is established with oneself, with others, and with the instruments and tools offered within the learning process. From that point on, the intention is to stimulate learning references that consider the relationships and connections between the knowledge, the tools used and the demands presented by the student's daily life.
\end{abstract}

With the use of technologies in education, teachers should create situations that allow students to apply the knowledge acquired in a contextualized way, in order to establish a connection between the knowledge obtained and the daily activities of school or life in general.

\section{The Teacher's Role in Technologies}

The use of computational resources is a challenge for many teachers in the various areas of education to develop their work, because questions and reflections on the use of technological tools in the classroom and the pedagogical potential of technologies are not yet widespread in society. Many of them lack the skills needed to adopt available tooling.

The use of technologies in teaching requires different methodologies from traditional ones, focused on lectures, in which teachers were the transmitters of knowledge and students the recipients.

For the use of technologies as a didacticpedagogical resource, it is important to take into consideration three aspects that determine its potentialities and effectiveness: first, the need to incorporate technology in the classroom; second, reflection among teachers and school educators on the objectives, methodology and methods of evaluating the efficiency of the adopted resources; third, provide teachers with training in tools that will be used in the classroom or in computer labs.

Teachers who use tools like computers or mobile devices, even during school hours, encourage their students to also use technology to be better prepared for college, for tomorrow's jobs, which will make them become best students and professionals [12].

In this context, it is clear that, for the implementation of digital technologies, it is necessary that at school there are qualified and qualified teachers in educational technologies, because these professionals have the function of guiding, 
stimulating and coordinating the use of technological tools by students. in the most different disciplines.

Teachers should encourage participation and collaboration through digital equipment. Teachers need to stimulate the creativity, reflection and practice of a new education based on the use of technologies, because an education focused on the repetition and passivity of students before a blackboard can no longer be part of society, which is focused on new ways of learning through technological resources, be they social networks, instant tools or application and educational software.

For Lopes [13] says that "[...] teachers should reflect on the new reality of existing teaching, seeking to rethink their practice and develop new ways of learning to achieve improvements". This statement is complemented by Sanches [14], who says that "the teacher cannot close his eyes to this reality, but must add this resource to his teaching didactics, because he must be the mediator between technological environments and students."

The pedagogical experience of the teacher and his qualification in the use of digital technological tools are fundamental for him to be the mediator in the teaching-learning process. He should know computer skills for carrying out classroom activities, such as discussions, activities and assessments, and know what it means to build knowledge.

For Tajra [15] states that the use of technology helps in the teaching-learning process, and the teacher should act as a facilitator of this process, as he needs to be able to deal with rapid changes and be dynamic and flexible with the new education.

Training in computational resources for teachers should focus on instructional strategies that incorporate technological skills in the teachinglearning process.

Technology in education is commonly defined as a technical device or tool used to promote learning. Educational technology may include media, projected and non-projected models, visual, sound and dynamic, using audio and video or all of them with digital media.

\section{The Convergence Between Education, Computer Resources, Teacher and Student}

It can be taken for granted that interactive communication systems in virtual environments and platforms will continue to grow due to the improvements in technological tools and the dynamism that education today requires, that is, an education in which students are the focus of the teaching process-learning.

The classroom and computer labs are no longer the same, since computing resources have become one of the tools teachers have to enrich their classes and make them more efficient.

According to Soffa and Alcântara [16], for the effective implementation of technological resources in education, four aspects are essential: the environments, the tools, the qualified teacher and the interested student, none of which predominates over the others.

Computational resources are learning tools. Learning occurs when the student performs a task and/or an activity through technological means, and the answers obtained make him build his own knowledge.

In this context, the student becomes the subject of their learning. For Derntl and Motschnig-Pitrik [17] argue that technologies have the potential to play a significant role with a more effective approach, in terms of deepening and lifelong learning processes.

According to these authors, computer resources have been shown to be able to assist people in organizing, transferring and managing information. Thus, technological tools have contributed to promote the individual study of students, interaction in lectures and experimentation for learning in practical classes.

The Fig. 2 illustrates the convergence between the use of computational resources and education, and the intersection of these two constructs are interdisciplinary projects for the conception of practical work with the use of computational resources by students in the classroom, with teachers as mediators in the classroom elaboration of these works.

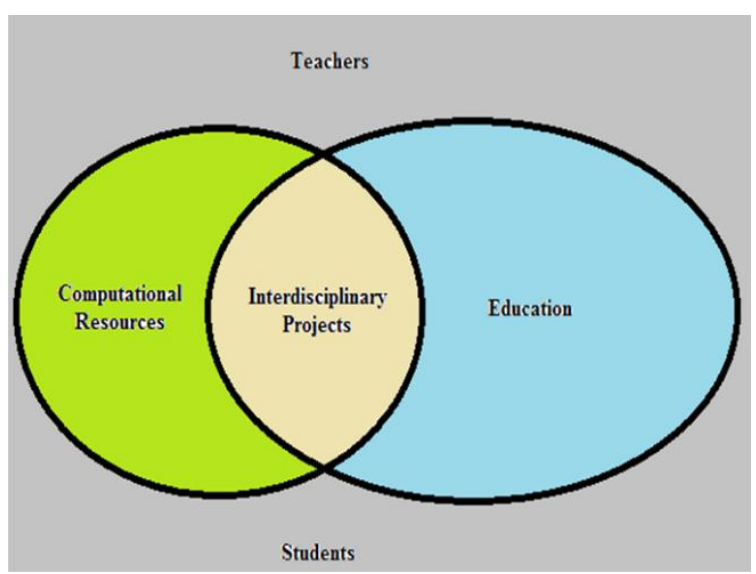

Figure 2. Convergence between the use of computer resources and education

At IFMG, Ponte Nova Campus and São João Evangelista, computational resources have been used as aids in the teaching-learning process through interdisciplinary projects, as mentioned above.

These projects are planned by the teachers and executed by the students, so that teachers can verify the evolution of students' knowledge of the subjects in 
the technical areas of technology offered by the institute.

According to the National Curriculum Guidelines, integrated education requires: "an interdisciplinary approach to curriculum organization and management, made possible by collectively developed work, previously planned, integrated and agreed with the educational community" [18].

In this context, it is evident that an integrated educational plan among school managers, teachers, educators, parents or guardians of students benefits the development of a curriculum that addresses the educational needs of students regarding computing resources, leading to learning and construction of knowledge. In the case of this study, the computational resource selected was the Virtual Tutor.

An integrated educational plan presupposes a partnership between teacher and student, which is consolidated by the use of educational technological tools to develop critical thinking, creativity, motivation, interaction, exchange of experiences, autonomy and rewards, producing emotional reactions of joy, euphoria, satisfaction, accomplishment and self-confidence in completing the proposed tasks, giving new meaning to the term learning.

\section{Methodology}

The research had the case study method, as it focused on the educational process developed with the adoption of virtual tutors in an Educational Institution of Federal Public Education. Case study is a method that includes planning, data collection techniques, and data analysis approaches [19].

The character of the research is qualitative, because according to Moresi [20]: "says that qualitative research allows identifying key questions and asking questions". The students' answers to the open questionnaires applied by the researcher were qualitatively analyzed, seeking to infer the respondents' opinions regarding the use of virtual tutors, which were used in the classroom and/or in the computer lab.

For the data gathering, a questionnaire consisting of ten open questions related to the use of the Virtual Tutor in support of the content taught in the discipline selected for study was applied to the students. The collected data were analyzed and qualitatively transcribed.

The use of the virtual tutor accessed by telegram was used by two hundred and fifty students of the technical computer courses in two different campuses of the Federal Institute of Minas Gerais (Ponte Nova and São João Evangelista). They answered the questionnaires applied in the English, High School/Technical discipline.
The technological resource used in the classroom and object of study was:

- Virtual Tutor, where students interacted with the technological tool through telegram. Using the messaging tool, the student had two options: Grammar Training and Pronunciation Training. In the end there was a ranking of scores. As the student progressed in the activity, the exercises increased the degree of difficulty.

The questionnaires were applied from June 20 to 24, 2018 in the computer labs of the Ponte Nova and São João Evangelista Campuses, for the students who participated in this research.

The virtual tutor was built for the purpose of being used in the English subject. This tutor was completed on April 15, 2018, after numerous tests on the proposed activities, grammar and pronunciation, in the language selected for the study.

\section{Data Analysis and Discussion of Results}

In the qualitative research, the descriptive analysis of the questionnaires was performed through the answers of the open questions, because the students used the virtual tutors as an auxiliary tool in learning English. The answers to the questionnaire were analyzed focusing on the students' perception regarding the use of virtual tutors, highlighting the adequacy of technologies to the content, the students' acceptance in their use in the classroom and/or computer lab, communication/interaction. With the tools, the available resources and the satisfaction achieved by the student with the result obtained with the use of the technological tool selected for the research.

The use of tutors to assist the students' learning process in the classroom and/or computer lab occurred in a practical way. The teachers of the subject exposed the contents of the lectures with the aid of datashow and the students, through the virtual tutor adopted in the course, practiced the contents on their mobile phones - "iPhones or smartphones".

Through the application of the questionnaires, we sought to reach an analysis about the adoption of tutors as a teaching innovation and to report experiences in the classroom and/or computer lab as a result of the use of virtual tutors in the learning process.

The questions were asked so that tutors' characteristics could be analyzed in relation to the following aspects: the use of the technological tool in the classroom and/or computer lab, friendly interface, adequate vocabulary in relation to the teaching modality, interaction and analysis of student learning with and without the use of the technological tool. 
Regarding the use of the tutor in the classroom, about $82,20 \%$ of the respondents said that the contents proposed in the classroom were worked in relation to pronunciation and grammar, causing teachers to release at the end of the class. Questions about the content seen on the day for student responses in order to support learning and increase interaction between teachers and students. Corroborating this idea, by [15] states that, although the use of technology assists the teaching-learning process, the teacher should direct students in the use of technological tools, so as not to disperse learning in the classroom. class.

The user-friendly and intuitive interface is of great importance in a technological tool, $98,90 \%$ of the students answered that the tutor's interface is easy to use and the buttons are intuitive in choosing some answer option. To Soffa and Alcântara [16], "the interface is the means of interaction with the user, because through illustrations, animations, colors and sounds can arouse, motivate, maintain and reinforce the student's attention".

The vocabulary used in tutors is simple and appropriate to the teaching modality of the study. Computer science students reported in the questionnaire answers that the language is easy to understand and understand. About $99,80 \%$ of the students answered that the words used in the Virtual Tutor were simple and non-erudite, the vocabulary used ensured the comprehension of the contents proposed in the daily and evaluative activities applied by the teachers through the technological tool. For Graells [11], states that through appropriate stimulation and vocabulary, the individual can exercise and promote their own knowledge in the construction of their learning.

Interaction is a key factor for the use of the tutor for the learning process, as there was interaction between the contents proposed in the subjects with their use, because with the use of technological tools, there was motivation of students regarding the discipline and they interested more in the classes. About $99,90 \%$ of the students reported that they could interact better with the technological tool than with the activities written and answered in the notebook. According to Tajra [15], despite the use of assistive technology in the teaching-learning process, the teacher should act as a facilitator and coordinator of student learning, because they need to deal with rapid changes and be dynamic and flexible.

Regarding the analysis of student learning with and without the use of the tutor in English language learning, $100,00 \%$ of respondents said that with the use of tutors the learning was better and more dynamic than just past lessons answered in the English language. Notebook, because there was less dispersion and better performance with the use of Virtual Tutor in classes. According to Moraes and De souza [7], "during class students are led to research and study individually, as well as to seek new information and data to bring to study and class discussions". Emphasis is on active and interactive learning in small groups.

With the qualitative analysis performed it can be stated that: the proper use of tutors was a pedagogical tool of fundamental importance in school practice, because these technological tools could be facilitators in the teaching-learning process in a teaching institution, as it is verified that with the implementation of the technological tool in the classroom, students participated actively in their learning process.

The teacher, assuming the role of encouraging an education based on the use of technologies, opens new ways for more meaningful learning, making the school environment more pleasant, dynamic and motivating for the construction of knowledge.

Learning is most significant when new content is incorporated into the student's knowledge structures and acquires meaning for them from the relationship they have with their prior knowledge.

\section{Conclusion}

The paper analyzed the use of virtual tutor in the learning process of the content taught in the selected subject in the study: English Language. It was noticed that the use of virtual tutors created different options and brought pedagogical advances in the teachinglearning process, as it acted as a tool that stimulated the teacher's work in search of a more dynamic and interactive classroom education.

The result of the application of the questionnaires showed that the students realized that there is a relationship that favored the use of the virtual tutor and the learning. Due to the results of the qualitative analysis, the technological tool used in the research, the virtual tutor, was accepted as a pedagogical support in the transmission of the syllabus by the teacher.

In the qualitative analysis it was noticed $100,00 \%$ of the students said that with the use of tutors the learning was better and more dynamic than just with past and answered lessons in the notebook, and this proved that the students tend to use it with more constancy as a pedagogical tool in the teachinglearning process, because the technological tool if well used, the student tends to be less dispersed in relation to the content passed on in the discipline.

It was noticed with the use of tutors in education, that the school environment needs constant monitoring and evaluation by a multidisciplinary team at school, made up of teachers, educators and teaching director. Such assessment should be continuous and formalized through the teaching plans, in order to support and support the students' learning process, so that pedagogical interventions can be carried out on time, optimizing the results of the use of technologies 
in education and providing reflection on the learning process of students in the classroom.

Among the limitation of the study, it was highlighted that only a qualitative analysis was performed and that a quantitative analysis could cover more students' opinions regarding the use of a technological tool, expanding the research from the point of view of classroom learning.

As a suggestion for future research, extend this study to other disciplines of the basic areas in order to verify the use of technological tools in the learning process of students.

It is expected, with the results of this study, to stimulate the teachers of other subjects to use virtual tutors in the classes, because it was realized that, with its use, the students interest and learning increased and the classes became more attractive for the students constant interaction that the Virtual Tutor provided with the syllabus of the course.

\section{Acknowledgments}

To all the teachers and students who participated in this study and to the leaders of the Campuses of the Federal Institute of Minas Gerais - Ponte Nova and São João Evangelista. To the Graduate Program in Information Systems and Knowledge Management PGPISKM from FUMEC University, located in the city of Belo Horizonte.

\section{References}

[1] Mauldin, M. L., (2013). CHATTERBOTS, TINYMUDS, AND THE TURING TEST: Entering the Loebner Prize Competition. Proceedings of the 12th National Conference on Artificial Intelligence (Seattle, WA, USA, July 31 - August 4).

[2] Bohn, C. S. (2011). A mediação dos jogos eletrônicos como estímulo do processo de ensino-aprendizagem. $154 \mathrm{f}$. Dissertação (Mestrado em Engenharia e Gestão do Conhecimento) - Centro Tecnológico, Programa de PósGraduação em Engenharia e Gestão do Conhecimento, Universidade Federal de Santa Catarina, Florianópolis.

[3] Quatrin, GABRIELA, and Beatriz, WILMA (2015). Ensino de Inglês na Escola pública e suas possíveis dificuldades. Thaumazein, Santa Maria, v.7, n. 14, pp. 1219.

[4] Pozzebon E., Frigo, L.B., and Bittencourt, G. (2014). MathTutor: Uma Ferramenta de Apoio a Aprendizagem. Anais do XXII Congresso da Sociedade Brasileira de Computação XWEI, Florianópolis.

[5] Urretavizcaya, L. M., (2001). Sistemas Inteligentes em el âmbito de la educación. Revista Iberoamericana de Inteligência Artificial. v. 1, n. 12, pp. 5-12.

[6] Leonhardt, M. D., (2003). Elektra: um chatterbot para uso em ambiente educacional. RENOTE, v. 1, n. 2, pp. 1723. Acedido em 15 de setembro de 2019 em, http://seer.ufrgs.br/index.php/renote/article/view/14336/82 51.

[7] Moraes, S. M. W., and De souza, L. S., (2015). Uma Abordagem Semiautomática para Expansão e Enriquecimento Linguístico de Bases AIML para Chatbots. In: Congresso Internacional de Informática Educativa, 20., Santiago. Anais. Santiago: Universidad de Chile, pp. 600605 .

[8] Dyke, G., (2013). Enhancing Scientific Reasoning and Discussion with Conversational Agents. IEEE Transactions on Learning Technologies, v. 6, n. 3, pp. 12-27.

[9] Perrenoud, P., (2009). O nó da avaliação. Pátio Revista Pedagógica, Porto Alegre, Artmed, v. 3, n. 50, ano XIII, pp. 8-11. Acedido em 6 de fevereiro de 2019 em, http://www.unige.ch/fapse/SSE/teachers/perrenoud/php_m ain/Textes2009.html.

[10] Jonassen, D., (2007). Computadores e Ferramentas Cognitivas. Porto: Porto Editora.

[11] Graells, P., (2007). Os métodos didáticos na educação à distância. 2. ed. São Paulo: Atlas.

[12] Rocha, M. M. S. da; Moura, M. Z. da S.; and Fhiladelfio, J. A. (Org.) (2013). Educação à distância: inclusão e tecnologia. São João del-Rei: UFSJ. Acedido em 27 de novembro de 2019 em, http://nead.ufsj.edu.br/Seminario/wp-content/uploads/2014/02/anaisnead2seminario. pdf.

[13] Lopes, J. J., (2004). A introdução da informática no ambiente escolar. Rio Claro: [s.n.]. Acedido em 22 de outubro de $2019 \mathrm{em}$, http://www.clubedoprofessor.com.br /artigos/artigojunio.pdf.

[14] Sanches, V. J. C. Tecnologia para inovações na didática do ensino: um estudo de caso (2008). Lousa Eletrônica. Acedido em 20 de novembro de 2019 em, http://www2.dc.uel.br/nourau/document/?down=742.

[15] Tajra, S. F., (2012). Informática na educação: novas ferramentas pedagógicas para o professor na atualidade. 9 . ed. rev. e ampl. São Paulo: Érica.

[16] Soffa, M. M.; and Alcântara, P. R. de C. (2018). O uso do software educativo: reflexões da prática docente na sala informatizada. In: CONGRESSO NACIONAL DE EDUCAÇÃO (EDUCERE), 8., 2018, Curitiba. Anais eletrônicos... Curitiba: PUCPR. Acedido em 29 de novembro de $2019 \mathrm{em}$, http://www.pucpr.br/eventos/educe re/educere2018/anais/pdf/335_357.pdf.

[17] Derntl, M.; and Motschnig-Pitrik, R. (2005). The role of structure, patterns, and people in blended learning. The Internet and Higher Education, v. 8, n. 2, pp. 111-130. Acedido em 12 de agosto de 2019 em, http://www.anitacrawley.net/Articles/Dernt1\%202005.pdf.

[18] Brasil (2013). Diretrizes Curriculares Nacionais Gerais da Educação Básica. Brasília: MEC/SEB/DICEI. 
[19] Acevedo, C. R., and Nohara, J. J. (2007). Monografias no Curso de Administração: Guia Completo de Conteúdo e Forma (3. ed.). São Paulo: Atlas.

[20] Moresi, E. A. D. (Org.). (2003). Manual de Metodologia da Pesquisa. Brasília: Universidade Católica de Brasília. 